\title{
DEVELOPING FLASH MEDIA OF QURANIC-BASED HUMAN REPRODUCTION SYSTEM MATERIAL
}

\author{
Arif Didik Kurniawan*, Nuri Dewi Muldayanti, and Banita Eka Putri \\ Department of Biology Education, Faculty of Teacher Training and Education, \\ Universitas Muhammadiyah Pontianak, Pontianak, West Kalimantan, Indonesia \\ *Corresponding e-mail: arifdidikk@gmail.com
}

\begin{abstract}
The problem of implementing Islamic values in the learning process is one of the concerns in Islamicbased schools, in particular, Rahmatan Lil'alamin Islamic Senior High School in Pontianak. This study aimed to develop learning media based on the Quran verses in the human reproduction system using Macromedia Flash software. This research and development used three phases of the 4D model developed by Thiagarajan, namely define, design, and development. The development results were validated by expert appraisal consisted of instructional review (appropriateness, effectiveness, feasibility) and technical review (media and language). Instruments used in this study were interview guide sheet (define phase), validation sheets, student response questionnaires, and post-test for product trial (development phase). Product trials were carried out by testing large groups consisted of 64 students majoring in social science at Rahmatan Lil'alamin Islamic Senior High School. The expert appraisal results showed that media reached "very valid" criteria with the validation scores 83.33 (instructional review), 80.42 (media), and 85.00 (language). Therefore, the flash media of Quranic-based human reproduction system material is potential to be used as media in teaching Islamic values integrated within the learning process.
\end{abstract}

Keywords: Human reproduction system, learning media, Macromedia flash, Quranic verses

\section{INTRODUCTION}

Media can be applied in almost any discipline to improve learning, both in class and for out-of-class assignments. Learning media appearance can be used to stimulate thoughts, feelings, and abilities or skills of learners (Ahmadi, Fakhruddin, Trimurtini, \& Khasanah, 2017; Anwariningsih \& Ernawati, 2013; Chen \& Chen, 2011; Firdausi, Prabawa, \& Sutarno, 2017; Salomon, 1979). According to Wahyuningsih, Jamaluddin, \& Karnan, (2015), the role of learning media in the learning process can enhance students' motivation in studying. This is in accordance with the opinion of Arsyad (2009) that learning media can clarify the presentation of information so that it can facilitate the learning process. For this reason, learning media become one of the important factors in the achievement of students' competencies.

In line with the development of science and technology, teachers must be able to utilize it and the potential of the surrounding environment, both natural and social processes as learning media. The teachers can define and design effective and powerful teaching and learning systems based on learning media that will be responsive to student needs (Onyenemezu \& Olumati, 2014; Oyedele, Rwambiwa, \& Mamvuto, 2013; Pandey, 2012). Besides that, the teacher is expected to be able to determine the learning media in accordance with the characteristics of the material delivered, such as in biology material. Specific learning media is needed in some learning activities to make the student understand more easily and clearly.

Biology, as a science related to life and nature, becomes one subject that is less attractive to students. Indonesian students have the "memorizing" mindset in biology learning. It is because the learning system is less able to use the media to help students learn. Therefore, it is necessary to develop an interactive-based learning media to promote student's interest in biology learning (Anwariningsih \& Ernawati, 2013; Chen \& Chen, 2011; Hamidi, 
Kharamideh, \& Ghorbandordinejad, 2011; Karno, 2015; Putra, Ardi, \& Leilani, 2017; Rizky R, Noranita, \& Wirawan, 2013) which is in line with the curriculum in Indonesia. One of the learning media that can be used in the learning process is Macromedia Flash.

Macromedia Flash is software that is used to create an animation in the form of images or writing in order to improve students' understanding on the lesson (Darmawan, 2011; Karno, 2015; Safitri, Hartono, \& Somakim, 2013; Wahyuningsih et al., 2015). It is suitable to be used in biology learning because many biological materials are abstract and difficult to understand. One of the abstract materials in biology subject is the material of the human reproduction system. With the help of Macromedia Flash as a learning media, it is expected that students can comprehend reproduction system material more easily. According to research conducted by (Karno, 2015), student learning outcomes using Macromedia Flash are better than those who do not apply the mentioned media.

Characteristics of Macromedia Flash besides being able to display the contents of the subject matter can also be inserted with other messages, such as religious value. The learning of religious values is closely related to Islamicbased schools, in particular, Rahmatan Lil'alamin Islamic Senior High School in Pontianak. In fact they have difficulty to implement Islamic values in the learning process. Therefore the development of Islamic value-based media using Macromedia Flash can be the answer to this problem. According to Fitri (2012) character building (e.g Islamic value) can be integrated into every learning process, every subject needs to be developed and associated with daily life. Technology can be used to educate Islamic value to the students (Al-Mosa, 2015; Lubis et al., 2011; Masum, Ullah, \& Azad, 2011).

Islamic value can be integrated with materials in Biology subject because it's discussing the intricacies of living things, the environment and the interaction between the two. Many verses of the Quran have links with biology materials, i.e. embryology, zoology, botany, ecology, reproduction, genetics, medicine, agriculture, and so on. Teachers have a big role to accommodate the Islamic value in students' learning (Elhoshi, Embong, Bioumy, Abdullah, \& Nawi, 2017; Tan, 2014). This study aimed to develop learning media based on the Quran verses in the human reproduction system using Macromedia Flash software.

\section{METHOD}

This research and development used three phases of the 4D model developed by Thiagarajan, Semmel, \& Semmel (1974), namely define, design, and development phase. The dissemination phase was not regulated since the research objectives have been obtained at the phase of development, which is to develop a valid media. Instruments used in define phase was interview guide sheet, while in the development phase were validation sheets, student response questionnaire, and post-test. The interview was conducted with student and biology teacher as interviewees.

Media was designed and developed using Adobe Flash CS 5. It was developed based on the Quranic verses related to human reproduction system material for the second grade of senior high school student. The development results were validated by expert appraisal consisted of instructional review (appropriateness, effectiveness, feasibility) and technical review (media and language). Validation sheet was used to measure appropriateness, media, and language. Students' respond questionnaire was used to measure the feasibility of media. While post-test was used to measure the effectiveness of media by product trial. Product trials were carried out by testing large groups consisted of 64 students majoring in social science at Rahmatan Lil'alamin Islamic Senior High School in Mepawah district, Pontianak, West Kalimantan, Indonesia. The result of the validation sheet (appropriateness, media, and language) was analyzed using criteria as displayed in Table 1.

Table 1. Validity and practicality criteria of Macromedia Flash

\begin{tabular}{lc}
\hline \multicolumn{1}{c}{ Scores } & Qualifications \\
\hline $81.25 \leq \mathrm{x} \leq 100$ & Very Valid \\
$62.5 \leq \mathrm{x}<81.25$ & Valid \\
$43.75 \leq \mathrm{x}<62.5$ & Fair \\
$25 \leq \mathrm{x}<43.75$ & Poor \\
\hline
\end{tabular}

Source: Agatha, Prihatin, \& Narulita (2017)

The score of students' post-test was analyzed based on Minimum Criteria of Mastery (KKM-Kriteria Ketuntasan Minimal), as high as 75 . The students' classical 
Sambodo et al. / JPBI (Jurnal Pendidikan Biologi Indonesia) / 4 (3) (2018) pp. 235-242

completeness was analyzed using criteria in Table 2 .

Table 2. Students' classical completeness

\begin{tabular}{|c|c|}
\hline Classical completeness (\%) & Description \\
\hline$x>80$ & Very Good \\
\hline $60<x \leq 80$ & Good \\
\hline $40<x \leq 60$ & Fair \\
\hline $20<x \leq 40$ & Poor \\
\hline $\mathrm{x} \leq 20$ & Failed \\
\hline
\end{tabular}

Source: Widoyoko (2013)

\section{RESULTS AND DISCUSSION}

\section{Define phase}

The define phase was conducted to analyze the problem in Islamic-based schools, Rahmatan Lil'alamin Islamic Senior High School. There were front-end analysis, learner analysis, concepts analysis, and specifying instructional objectives.

The result of front-end analysis showed that during the learning process, the teacher used textbooks and student worksheets as learning media. In addition, based on learner analysis, there were $71.9 \%$ of the total students who had not reached the minimum criteria of mastery. It's showed that students find difficulties to understand the reproduction system material. Furthermore, the syllabi analysis stated that one of the competencies that must be achieved by students is a spiritual attitude. Students are expected to be able to live and practice the teachings of their belief (religion). It's confirmed that spiritual attitude (i.e. Islamic value) need to be integrated into the learning process. However, the teacher rarely linked the material taught with this value, as well as in the learning media. The textbook and student worksheet used in learning could not support Islamic value teaching for student.

The student analysis also measured by interviewing students in social science class. It is described the learning difficulties faced by students during the learning process. The results obtained from students' interview explained that the teacher seldom uses learning media which integrated with Islamic value during the learning process. So far, most teachers had only focused on delivering the material using textbooks and worksheets. Therefore, the need for learning media innovations is urgent, especially animation media to stimulate attention, interests, thoughts, and feelings of students in achieving learning objective (Sari \& Ulya, 2017; Sharma \& Pooja, 2016; Tileston, 2003; Wahyuningsih et al., 2015).
The results of concept analysis showed that the student competency in human reproduction system is:

"Students are able to analyze the relationship between the structure of composed tissue in reproductive organs and their functions in the process of human reproduction through literature studies, observations, experiments, and simulations".

In line with the analysis of the learning objectives, students were able to: 1) specify the reproduction organs of the reproduction system; 2) explain the functions of the reproduction system organ; 3) explain the function of the hormone; 4) explain the process of gametogenesis; and 5) explain the process of fertilization, gestation, and labor. Some of the primary concepts in reproduction system include gametogenesis, fertilization, and gestation (pregnancy). These concepts also explained in the Quran. For example in Quran Surah (Q.S.) Al-Mursalaat: 20-22 which explain embryo grows in the uterus:

"Did we not create you from contemptible water? Then we placed it in a secure restingplace, till an appointed term."

Based on the explanation above, learning media which can relate the material to the Islamic value (i.e. Quran verses) is needed. The developing of flash media of Quranic-based human reproduction system material must be appropriate with the objectives.

\section{Design Phase}

The initial designs of flash media of Quranic-based human reproduction system material were:

a) Introduction template consists of title and objective (Figure 1).

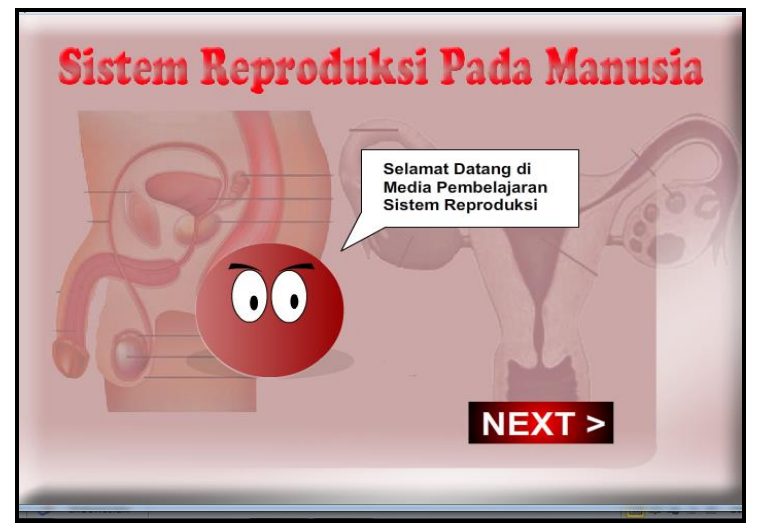

Figure 1. Introduction template. The 'next' button's function is to go the main menu 
b) The main template consists of learning material (Figure 2-3), video included into Macromedia Flash software frame (Figure 4), and evaluation tests (Figure 5). The Quran verses used are Q.S. Al-Waqi' ah: 58, Q.S. Al-'Alaq: 2, Q.S. An-Najm: 45-46, Q.S. Al-Qiyaamah: 37-39, Q.S. Al-Mursalat: 20-21, Q.S. At-Tariq: 6-7, Q.S. As-Sajdah: 7-9, Q.S. Al-'Infitaar: 7-8, and Q.S. AlMu'minuun: 67.

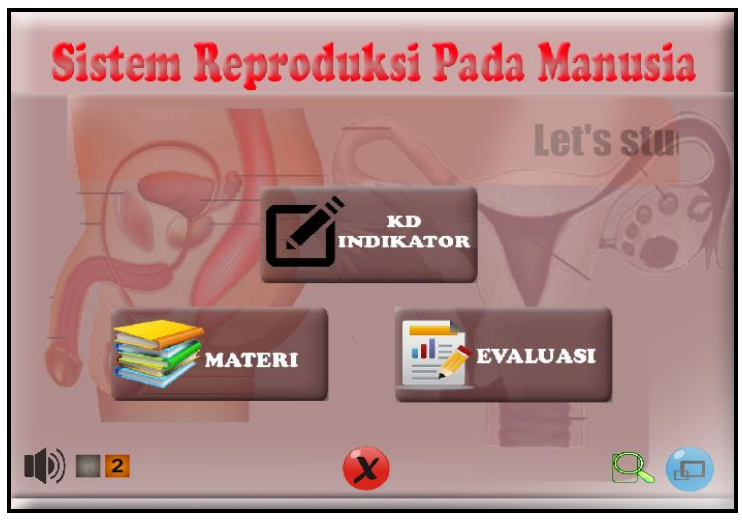

Figure 2. The main menu consists of learning competencies, indicators and materials.

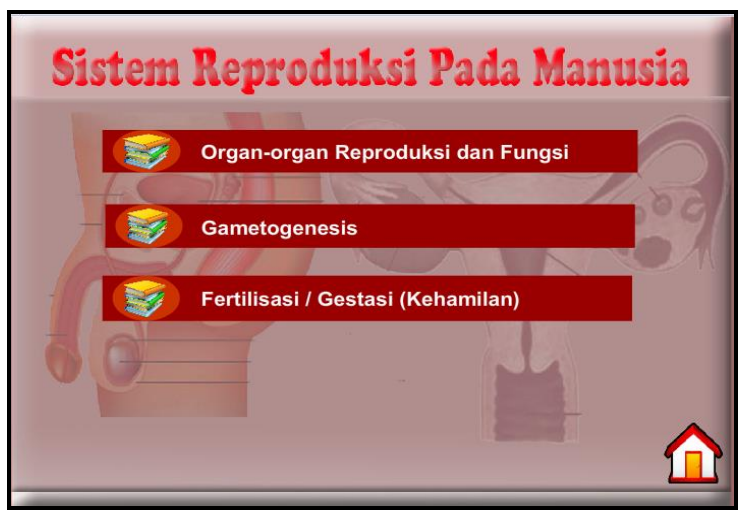

Figure 3. The materials template. Each topics has detailed explanation.

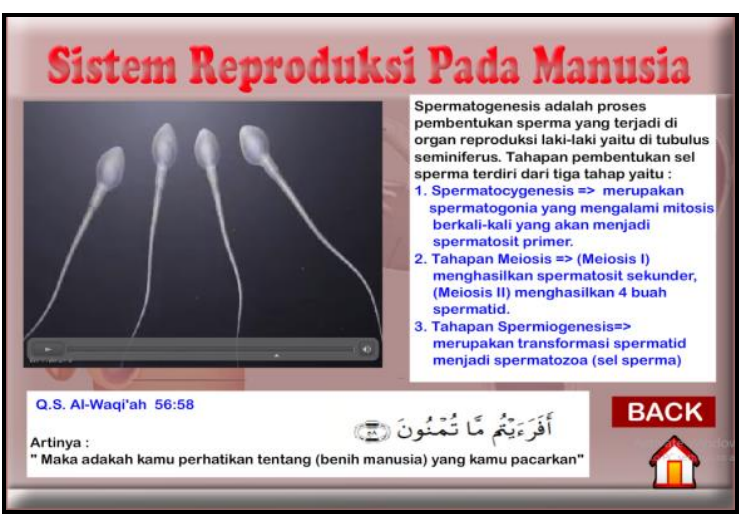

Figure 4. Animation video explains the process of spermatogenesis, oogenesis, and fertilization. The Quran verses related to each concept are inserted in the template.

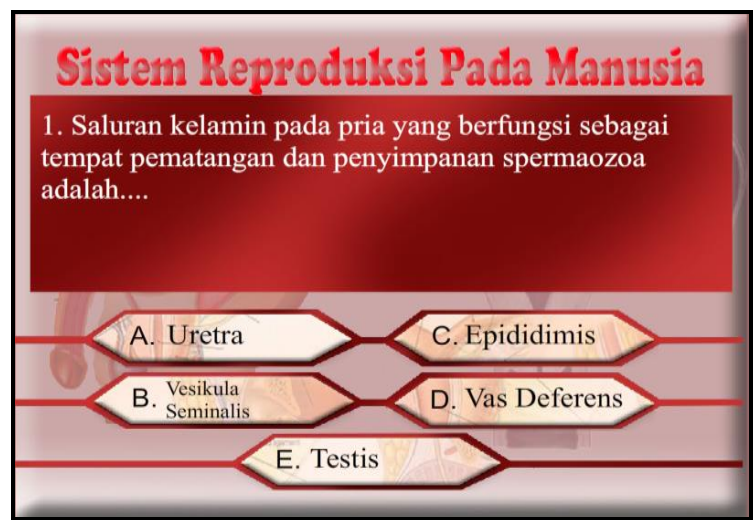

Figure 5. Evaluation template consists of multiple choice questions.

c) The closing template contains of references (Figure 6). References list can be used to help students to find and access other learning source.

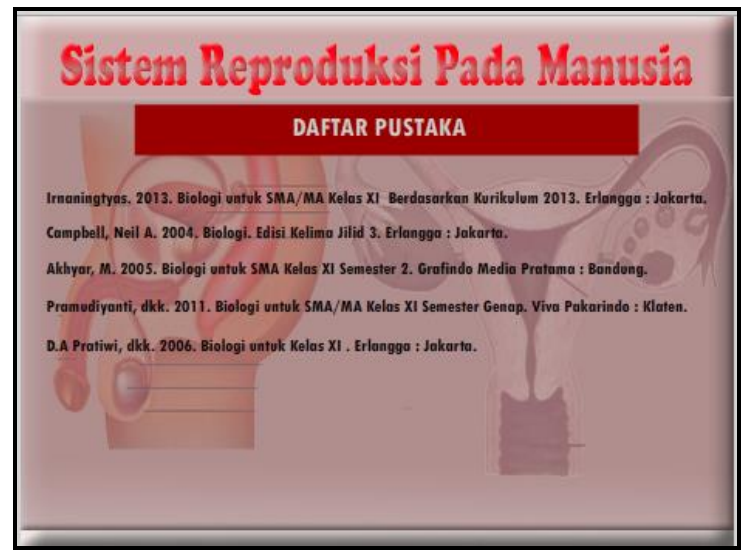

Figure 6. The template of references list.

\section{Development Phase}

There are expert appraisals consisted of instructional review and technical review in the development phase.

a) Instructional review

The purpose of this stage is to conduct the appropriateness review, feasibility review, and effectiveness review of developed media. Based on the validation result by material expert, developed media was appropriate to use with the score is 83.33 (very valid criteria). It could be informed that the material displayed in the media has already in accordance with the curriculum and learning objectives. It was explained that teaching materials must be relevant to the applicable curriculum (Anwariningsih \& Ernawati, 2013; Astatin \& Nurcahyo, 2016; Purwono, Yutmini, \& Anitah, 2014). 
Sambodo et al. / JPBI (Jurnal Pendidikan Biologi Indonesia) / 4 (3) (2018) pp. 235-242

Feasibility review measured by using students' respond questionnaire. The questionnaire result showed that the flash media of Quranic-based human reproduction system indicated good criteria (Table 3). Students are more motivated using the developed media. The animation video in the developed media makes student interested to learn (Ainsworth, 2008; Hamidi et al., 2011; Karno, 2015; Pruneski \& Donovan, 2007; Putra et al., 2017). It can be explained that the advantage of using multimedia in the learning process is the material becomes interactive and clearer because of the presence of sounds and pictures (Anwariningsih \& Ernawati, 2013; Chen \& Chen, 2011; Sharma \& Pooja, 2016). The multimedia gives variation learning forms such as listening to audios, watching videos, paying attention to pictures in the frame so that the students will not easily getting bored in studying the material.

Table 3. The students' questionnaire result

\begin{tabular}{|c|c|c|c|}
\hline No & Questions & Score $(\%)$ & Criteria \\
\hline 1 & $\begin{array}{l}\text { I am interested in learning activity of reproduction system using flash learning } \\
\text { media }(+)\end{array}$ & 79.43 & Good \\
\hline 2 & $\begin{array}{l}\text { Animation/simulation in flash learning media is clearly displayed and } \\
\text { interesting; it makes me easier to understand reproduction system material }(+)\end{array}$ & 80.00 & Good \\
\hline 3 & $\begin{array}{l}\text { I have difficulty to understand the teacher explanation with the use of flash } \\
\text { media }(-)\end{array}$ & 18.29 & Good \\
\hline 4 & $\begin{array}{l}\text { Flash media displays are very interesting; it increases my interest to learn more } \\
\text { about reproduction system material using flash media }(+)\end{array}$ & 76.00 & Good \\
\hline 5 & I can understand the text language and the voices used in flash media easily (+) & 80.00 & Good \\
\hline 6 & $\begin{array}{l}\text { Exercise questions presented in the media do not support my understanding } \\
\text { towards the learnt material }(-)\end{array}$ & 22.29 & Good \\
\hline 7 & $\begin{array}{l}\text { Narration/Voice/Music in the flash media are clearly heard and able to improve } \\
\text { my learning interest }(+)\end{array}$ & 79.43 & Good \\
\hline 8 & $\begin{array}{l}\text { I feel more unmotivated to learn the reproduction system material because of } \\
\text { the poor narration/music played in flash media }(-)\end{array}$ & 17.71 & Good \\
\hline 9 & $\begin{array}{l}\text { I am bored when the teacher explains the reproduction system material with } \\
\text { flash media }(-)\end{array}$ & 24.57 & Good \\
\hline 10 & $\begin{array}{l}\text { I can easily understand the material of reproduction system using flash media } \\
(+)\end{array}$ & 86.29 & Good \\
\hline 11 & I do not like the language and voices used in the flash media (-) & 16.00 & Good \\
\hline 12 & Flash learning media uses boring and dull display and color $(-)$ & 17.71 & Good \\
\hline 13 & $\begin{array}{l}\text { I do not like animation/simulation of reproduction system material in the flash } \\
\text { media because the material is hard to understand }(-)\end{array}$ & 22.29 & Good \\
\hline 14 & $\begin{array}{l}\text { I can answer the exercises in the flash learning media easily and it can improve } \\
\text { my understanding of reproduction system material }(+)\end{array}$ & 83.43 & Good \\
\hline
\end{tabular}

The effectiveness review of the media was measured using students' post-test score. This stage was seen as useful to grasp the extent to which the produced media can assist the achievement of learning objectives. The result showed that students' classical completeness was $93.75 \%$ which categorized as very good criteria. It can be concluded that the development of this media was classified as effective because it can improve student learning outcomes. The completeness of learning outcomes obtained after applying flash media was due to the improvement of students' learning motivation. Students' motivation increases because the Macromedia Flash has an appearance with animation. Macromedia Flash has an attractive appearance partnered with animations appropriated to the subject matter being studied (Ainsworth, 2008; Astatin \& Nurcahyo, 2016; Hwang, Tam, Lam, \& Lam, 2012; Pruneski \& Donovan, 2007; Wahyuningsih et al., 2015). The students become more active and pleased because the media provides pictures and information that can be understood better by the students and also it packed in a form of joyful learning.

The impact of increasing student motivation in learning influences the achievement of students' learning outcomes. The flash media can help students understand abstract material easily (Kusuma, Chamisijatin, \& Nurwidodo, 2015; Wahyuningsih et al., 2015). Besides the understanding of the material, students also can relate the material to the Quranic verses. The learning process by linking biological material with Quranic verses was rarely done by the 
teacher. This phenomenon made students more interested and motivated to participate in learning activities giving a positive impact on improving learning outcomes, as well as their Islamic value. Regarding that situation, flash media of Quranic-based human reproduction system supports the achievement of spiritual attitude as stated in syllabi.

\section{b) Technical review}

The purpose of this stage is to conduct the media review and language review of developed media. Based on the validation result by media expert, developed media was categorized as valid criteria (score $=80.42$ ). However, there are some suggestions from the media expert to improve the media, namely: 1) enlarging the display resolution for each frame to be $1024 \times 768 ; 2$ ) adding a hint icon in the mainframe to display instructions for using the flash media; 3) adding "a stop all sound" script for each frame to regulate the sound not to disturb other frames. The media was revised according to the validator suggestions. The revision process was conducted so that the media have better quality.

After that, the result of language review by expert reached very valid criteria (score = 85.00). According to Putra et al. (2017), language is a very significant aspect to convey information or material to the reader. In the learning process, language becomes an important thing because it's emphasized in how to move human or students to do the learning activity in accordance to achieve the determined competency (Wicaksono, 2016). For this reason, the role of language is crucial when the teacher delivers the material to students so that students are better prepared and understand the material being studied. According to Hamalik (2004), the readiness of students in learning affects the process of delivering learning information in the classroom.

Based on the expert appraisal results showed that flash media of Quranic-based human reproduction system material is potential to be used as media in teaching Islamic values integrated within the learning process.

\section{CONCLUSION}

The developed media in this research is flash media of Quranic-based human reproduction system using Macromedia Flash software. This media covers subject matter that is in accordance with the indicator of learning planned by the teacher. This media also includes video and Quranic verses to motivate students in studied biology with Islamic values. Based on the instructional review, media developed is appropriate (score $=83.33$ ), feasible and effective to use. As well as the technical review showed that media and language aspect is valid with the score about 80.42 and 85.00 respectively. Therefore, the flash media of Quranic-based human reproduction system material is potential to be used as media in teaching Islamic values integrated within the learning process.

\section{ACKNOWLEDGMENT}

This paper is supported by Directorate of Research and Community Empowerment of the Universitas Muhammadiyah Pontianak, West Kalimantan Province, Indonesia. The author wishes to recognize Mia Audina S.Pd and Dirga Mahardika for their contribution to this study.

\section{REFERENCES}

Agatha, N. D., Prihatin, J., \& Narulita, E. (2017). Pengembangan buku komik pokok bahasan sistem peredaran darah. JURNAL BIOEDUKATIKA, 5(2), 59-64. https://doi. org/10.26555/bioedukatika.v5i2.7200

Ahmadi, F., Fakhruddin, Trimurtini, \& Khasanah, K. (2017). The development of pop-up book media to improve 4th grade students' learning outcomes of civic education. In $3 r d$ International Conference on Theory and Practice (ICTP- 2017) (pp. 33-41). Adelaide, Australia: Asia Pacific Institute of Advanced Research (APIAR). Retrieved from https://apiar.org.au/wp-content/uplo ads/2017/08/5_ICTP_2017_BRR707_Edu -33-41.pdf

Ainsworth, S. (2008). How do animations influence learning? In D. H. Robinson \& G. Schraw (Eds.), Recent Innovations in Educational Technology that Facilitate Student Learning (Current Perspectives on Cognition, Learning and Instruction) (1st ed., pp. 1-51). Charlotte, NC: Information Age Publishing. Retrieved from http://www.csuchico.edu/ nschwartz /Ainsworth(2008).pdf

Al-Mosa, N. A. (2015). Role of social networks in developing religious and social values 
Sambodo et al. / JPBI (Jurnal Pendidikan Biologi Indonesia) / 4 (3) (2018) pp. 235-242

of the students of the world Islamic Sciences; Education University. International Education Studies, 8(9), 126-137. https://doi.org/10.5539/ies.v8n9 p126

Anwariningsih, S. H., \& Ernawati, S. (2013). Development of interactive media for ICT Learning at Elementary School based on student self learning. Journal of Education and Learning, 7(2), 121. https://doi.org/ 10.11591/edulearn.v7i2.226

Arsyad, A. (2009). Media pembelajaran. Jakarta: Raja Grafindo Persada.

Astatin, G. R., \& Nurcahyo, H. (2016). Pengembangan media pembelajaran biologi berbasis adobe flash untuk meningkatkan penguasaan kompetensi pada Kurikulum 2013. Jurnal Inovasi Pendidikan IPA, 2(2), 165-176. https:// doi.org/10.21831/jipi.v2i2.10966

Chen, C.-C., \& Chen, C.-M. (2011). The application of interactive media display technology in environmental science learning (pp. 484-488). Springer, Berlin, Heidelberg. https://doi.org/10.1007/978-3642-22095-1_97

Darmawan, D. (2011). Teknologi pembelajaran. Bandung: Remaja Rosdakarya.

Elhoshi, E. R. F., Embong, R., Bioumy, N., Abdullah, N. A., \& Nawi, M. A. A. (2017). The role of teachers in infusing Islamic values and ethics. International Journal of Academic Research in Business and Social Sciences, 7(5), 426-436. https://doi.org/10.6007/IJARBSS/v7-i5/29 80

Firdausi, N., Prabawa, H. ., \& Sutarno, H. (2017). Improve student understanding ability through gamification in instructional media based explicit instruction. Journal of Physics: Conference Series, 812. https://doi.org/10.1088/1742-6596/81 2/1/012069

Fitri, A. Z. (2012). Pendidikan karakter berbasis nilai \& estetika di sekolah. Yogyakarta: Ar-Ruzz Media.

Hamalik, O. (2004). Proses belajar mengajar. Jakarta: Bumi Aksara.

Hamidi, F., Kharamideh, Z. M., \& Ghorbandordinejad, F. (2011). Compari son of the training effects of interactive multimedia (CDs) and non-interactive media (films) on increasing learning speed, accuracy and memorization in biological science course. Procedia
Computer Science, 3, 144-148. https://doi. org/10.1016/j.procs.2010.12.025

Hwang, I., Tam, M., Lam, S. L., \& Lam, P. (2012). Review of use of animation as a supplementary learning material of physiology content. The Electronic Journal of E-Learning, 10(4), 368-377. Retrieved from http://www.ejel.org/ issue/download.html?idArticle $=216$

Karno, R. (2015). Penerapan media pembelajaran biologi dengan menggunakan Macromedia Flash Profesional 8. Edu Research, 4(1), 79-84. Retrieved from http://e-journal.upp.ac.id/index.php/EDU/ article/view/1198/pdf_43

Kusuma, P. S., Chamisijatin, L., \& Nurwidodo. (2015). Pengaruh macromedia flash terhadap hasil belajar siswa Kelas X IPA SMA Negeri 4 Pasuruan. In Prosiding Seminar Nasional Pendidikan Biologi 2015 (pp. 386-394). Malang: Prodi Pendidikan Biologi FKIP Universitas Muhammadiyah Malang. Retrieved from http://biology.umm.ac.id/files/file/386-394 Pranoto Sakti Kusuma.pdf

Lubis, M. A., Lampoh, A. A., Yunus, M. M., Shahar, S. N., Ishak, N. M., \& Muhamad, T. A. (2011). The use of ICT in teaching Islamic subjects in Brunei Darussalam. In Proceedings International Conference on Education and Educational Technologies (pp. 212-217). Elsevier B.V. Retrieved from https://ukm.pure.elsevier.com/en/pub lications/the-use-of-ict-in-teaching-islamic -subjects-in-brunei-darussalam

Masum, A. K. M., Ullah, M. C., \& Azad, M. A. K. (2011). Information technology (IT) ethics in the light of Islam. IIUC Studies, 9, 243-260. https://doi.org/10.3329/iiucs. v9i0.24030

Onyenemezu, C. E., \& Olumati, E. S. (2014). Educational media and technology: A panacea for effective teaching and learning among trainee adult educators in University of Port Harcourt. British Journal of Education, 2(3), 75-81. Retrieved from http://www.eajournals.org/ wp-content/uploads/Educational-Mediaand-Technology-A-Panacea-for-EffectiveTeaching-and-Learning-among-Trainee. pdf

Oyedele, V., Rwambiwa, J., \& Mamvuto, A. (2013). Using educational media and technology in teaching and learning processes: A case of trainee teachers at 
Africa University. Academic Research International, 4(1), 292-300. Retrieved from http://www.savap.org.pk/journals/A RInt./Vol.4(1)/2013(4.1-30).pdf

Pandey, A. K. (2012). Electronic media based e-education model for media persons. International Journal of Education and Psychological Research (IJEPR), 1(1), 12-18. Retrieved from http://ijepr.org/doc/ V1_Is1_July 12/3.pdf

Pruneski, J., \& Donovan, S. (2007). The use of animations in undergraduate biology education: Going beyond the content! Pittsburgh. Retrieved from http://www. pitt.edu/ sdonovan/lab/products/POGIL animation poster2.pdf

Purwono, J., Yutmini, S., \& Anitah, S. (2014). Penggunaan media Aadio-visual pada mata pelajaran Ilmu Pengetahuan Alam di Sekolah Menengah Pertama Negeri 1. Jurnal Teknologi Pendidikan Dan Pembelajaran, 2(2), 18. Retrieved from http://www.jurnal.fkip.uns.ac.id/index.php /tp/article/view/3659

Putra, B. F., Ardi, A., \& Leilani, I. (2017). Pengembangan media pembelajaran interaktif menggunakan aplikasi flash flip book tentang materi animalia untuk peserta didik Kelas X SMAN 1 Pariaman. Journal Biosains, 1(2), 165-173. Retrievd from http://ejurnal.bunghatta.ac. id/index. php?journal $=$ JFKIP \& page $=$ article $\& o p=v i$ ewFile\&path[]=6034\&path[]=5104

Rizky R, D., Noranita, B., \& Wirawan, P. W. (2013). Aplikasi pembelajaran biologi interaktif bagi siswa Kelas VIII. Journal of Informatics and Technology, 2(2), 5965. Retrieved from https://ejournal3.undip. ac.id/index.php/joint/article/view/6284

Safitri, M., Hartono, Y., \& Somakim. (2013). Development of learning media based macromedia flash about triangle for student Grade 7 Junior High School. In Zulkardi (Ed.), Proceeding The First South East Asia Design/Development Research (SEA-DR) International Conference (pp. 241-250). Palembang: UNSRI. Retrieved from http://eprints. unsri.ac.id/2431/1/P28_Meilani_S_250.pd f

Salomon, G. (1979). Media and symbol systems as related to cognition and learning. Journal of Educational Psychology, 71(2), 131-148. https://doi.org/10.1037/00220663.71.2.131
Sari, S. A., \& Ulya, A. (2017). The development of pop-up book on the role of buffer in the living body. Europan Journal of Social Sciencer Education and Research, 10(2), 213-221. Retrieved from http://journals.euser.org/index.php/ejser/ar ticle/view/2430/2390

Sharma, H. L., \& Pooja, P. (2016). Enhancing students interest in English language via multimedia presentation. Inernational Journal of Aplied Research, 2(1), 275281. Retrieved from http://www.all researchjournal.com/archives/2016/vol2iss ue1/PartE/1-13-150.pdf

Tan, C. (2014). Educative tradition and Islamic schools in Indonesia. Journal of Arabic and Islamic Studies, 14, 47-62. Retrieved from https://www.lancaster.ac.uk/jais/volu me/docs/vol14/v14_03_tan_047-062.pdf

Thiagarajan, S., Semmel, D. S., \& Semmel, M. I. (1974). Instructional development for training teachers of exceptional children: A sourcebook. Council for Exceptional. Children, 1920 Association Drive, Reston, Virginia 22091. Retrieved from https:// files.eric.ed.gov/fulltext/ED090725.pdf

Tileston, D. W. (2003). The importance of media in the classroom. In What Every Teacher Should Know About Media and Technology (pp. 1-7). Dallas, Texas: Corwin. Retrieved from https://us.corwin. com/sites/default/files/upm-binaries/6635_ tileston_9_ch_1.pdf

Wahyuningsih, W., Jamaluddin, J., \& Karnan, K. (2015). Penerapan pembelajaran biologi berbasis Macromedia flash dan implikasinya terhadap keterampilan metakognitif dan penguasaan konsep siswa Kelas VIII SMPN 6 Mataram. Jurnal Pijar MIPA, 10(1), 41-46. Retrieved from http://jurnalfkip.unram.ac. id/index.php/JPM/article/view/16/16

Wicaksono, L. (2016). Bahasa dalam komunikasi pembelajaran. Journal of Prospective Learning, 1(2), 9-19. Retrieved from http://jurnal.untan.ac.id/ index.php/lp3m/article/download/19211/1 6053

Widoyoko, S. E. P. (2013). Evaluasi program pembelajaran: Panduan praktis bagi pendidik dan calon pendidik. Yogyakarta: Pustaka Pelajar. 